\title{
Determination of genetic structure in Barbus tauricus Kessler, 1877 populations inhabiting a few streams along the Black Sea Region (Turkey) inferred from mtDNA Cytochrome $b$ gene sequence analysis
}

\section{Karadeniz Bölgesi (Türkiye) boyunca bazı akarsularda yaşayan Barbus tauricus Kessler, 1877 populasyonlarının mtDNA Sitokrom b sekans analizleri ile genetik yapısının belirlenmesi}

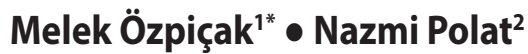 \\ 1 Ondokuz Mayis University, Faculty of Art and Sciences, Biology Department, 55139, Samsun, Turkey (iD https://orcid.org/0000-0003-3506-4242 \\ 2 Ondokuz Mayis University, Faculty of Art and Sciences, Biology Department, 55139, Samsun, Turkey iD https://orcid.org/0000-0001-9785-9927 \\ *Corresponding author: melek.zengin@omu.edu.tr
}

Received date: 17.04 .2018

Accepted date: 03.07.2018

How to cite this paper:
Özpiçak, M. \& Polat, N. (2019). Determination of genetic structure in Barbus tauricus Kessler, 1877 populations inhabiting a
few streams along the Black Sea Region (Turkey) inferred from mtDNA Cytochrome $b$ gene sequence analysis. Ege Journal
of Fisheries and Aquatic Sciences, 36(1), 1-11. DOI: 10.12714/egejfas.2019.36.1.01

Abstract: This study was carried out in order to determine the intra-specific variations in Barbus tauricus populations sampled from different localities in the Black Sea Region. A total of 250 B. tauricus samples were collected from inland waters (Akçay Stream (Samsun), Engiz Stream (Samsun), Terme Stream (Samsun) Karadere Stream (Trabzon) and Değirmenağzı Stream (Düzce)) of Black Sea Region. Intra-species variations in the species of $B$. tauricus were determined using mitochondrial DNA cyt $b$ squencing. The population genetic structure was revealed by analyzing the molecular variance (AMOVA). For this study, a member of the related fish group, Cyprinus carpio L., 1758 (DQ868874.1)(as an outgroup) and other Barbus species from the GENBANK database was used in comparative analyses. Therefore, total sequence of $1141 \mathrm{bp}$ of the cyt $b$ gene region was obtained and 11 haplotypes were determined. The molecular data obtained by AMOVA revealed that there were intraspecific variations of $B$. tauricus and that $26.61 \%$ of the variation were among the populations. The $F_{S T}$ value estimated for all populations and loci confirms genetic heterogeneity in $B$. tauricus populations $\left(\mathrm{F}_{\mathrm{ST}}=0.59310\right)$. Genetic analyses revealed that $B$. tauricus populations are geographically structured.

Keywords: Crimean barbel, genetic structure, cyt b, Black Sea, Turkey

Öz: Bu çalışma Karadeniz Bölgesi'ndeki farklı alanlardan örneklenen Barbus tauricus populasyonları arasındaki türiçi varyasyonları ortaya çıkarmak için gerçekleştirilmiştir. Karadeniz Bölgesi'ndeki farklı içsulardan (Akçay (Samsun), Engiz Çayı (Samsun), Terme Çayı (Samsun) Karadere (Trabzon) and Değirmenağzı Deresi (Düzce)) toplamda 250 örnek yakalanmıştır. Tür içi varyasyonlar mtDNA cyt $b$ sekansı kullanılarak saptanmıştır. Popülasyonların genetik yapıları moleküler varyans analizi (AMOVA) ile belirlenmiştir. Bu çalışmada GENBANK veri tabanından alınan Cyprinus carpio L., 1758 (DQ868874.1)(dış grup) ve diğer Barbus türleri karşılaştırmalı analizlerde kullanılmıştır. Cyt $b$ gen bölgesinin 1141 baz çiftlik toplam sekansı ve 11 haplotip elde edilmiştir. AMOVA analizinden elde edilen moleküler veriler B.tauricus türiçi varyasyonun varlığını ve varyasyonun \% 26.1 oranında gruplar arasında olduğunu ortaya çıkarmıştır. Tüm populasyonlardan elde edilen $F_{S T}$ değeri populasyonlardaki genetik heterojeniteyi doğrulamaktadır $\left(\mathrm{F}_{\mathrm{ST}}=0.59310\right)$. Genetik analizler, B. tauricus populasyonlarının coğrafik olarak farklılıklar gösterdiğini ortaya çıkarmıştır. 


\section{INTRODUCTION}

The taxonomic classification of organisms, and understanding the diversity of biological life, were usually based on descriptions of morphological forms (Adams et al., 2004). However, when there were phenotypically very similar species, there could be some confusion in the studies. In terms of fisheries management and biology, it is important to determine the phenotypic variation caused by environmental and genetic factors. In this way, a more accurate stock management plan can be created. The use of genetic techniques in fisheries science has revealed that many phenotypically different populations or genera are not genetically different. Sometimes it is quite difficult to explain the reasons of morphological differences between populations (Cadrin, 2000), but it is assumed that these differences may be genetically related or might be associated with phenotypic plasticity in response to different environmental factors (Murta, 2000). Population genetic bottleneck, geographic isolation, living environment, gene flow, and natural selection have large effects on the genetic construction of populations (Li et al., 2007). It has been found that biogeography and long-term climate changes first influence the genetic diversity and morphological variations in the species with so many studies to date (Stiling, 1992; Raven and Johnson, 1995; Cabral et al., 2003; Pinheiro et al., 2005; Mahe et al., 2014).

In recent years, many molecular techniques have been developed and Mitochondrial DNA (mtDNA) sequencing is one of the these techniques. mtDNA is the most studied part of the animal genome because of many reasons (Avise, 1986). Mitochondria are semi-autonomous organelles possessing their own genome and the machinery for its replication, transcription and for protein synthesis (Saccone et al., 2000). Mitochondrial DNA requires fewer individuals and find the source of the various haplotypes among geographical regions faster than any nuclear markers (Maes et al., 2003) and one of the most studied parts of the genome in population studies (Tsigenopoulos et al., 2002; Kotlík et al., 2008; Myoung and Kim, 2014; Im et al., 2017). Mitochondrial DNA of animals consists of 37 coding genes ( 22 tRNA, 2 rRNA, 13 proteins) and one noncoding region. It has been reported that cyt $b$ genes differ in population level. Consequently, this region was preferred for a lot of studies (Gilles et al., 1998; Aboim et al., 2005; Sevilla et al., 2007; Rylková et al., 2013; Kartavtsev et al., 2017; Kumar et al., 2017).

Cyprinidae is the most preferred fish family with systematic and phylogeny studies. The world's largest freshwater fish fauna (with highest number of species) belongs to the Cyprinidae, with over 200 genus and over 2100 species (He et al., 2008). Barbus tauricus Kessler, 1877 is a widely distributed fish species in Blacksea watersheds (Kottelat and Freyhof 2007). Tauricus, the genus epithelium, comes from Tauris and Taurida, the names of the Crimean Peninsula in ancient Greek and Latin (Bănărescu and Bogutskaya, 2003).

The aim of this study was to examine the intraspecific variation in B. tauricus populations sampled from different localities in the Black Sea Region by using mtDNA cyt $b$ region.

\section{MATERIAL AND METHODS}

\section{Sampling}

A total of 250 B. tauricus samples were collected from inlandwaters (Akçay Stream (Samsun), Engiz Stream (Samsun), Terme Stream (Samsun) Karadere Stream (Trabzon) and Değirmenağzı Stream (Düzce)) of Black Sea Region with electroshocker (Table 1-Figure 1).

Table 1. Coordinates of sampling locations

\begin{tabular}{ccc}
\hline Locality & Coordinates & Sampling Time \\
\hline Karadere Stream & $40^{\circ} 51^{\prime} 54.43^{\prime \prime} \mathrm{N}$ & August 2015 \\
$40^{\circ} 1^{\prime} 10.06^{\prime \prime} \mathrm{E}$ & \\
Değirmenağzı & $41^{\circ} 05^{\prime} 07.21^{\prime \prime} \mathrm{N}$ & July 2016 \\
Stream & $31^{\circ} 06^{\prime} 06.50^{\prime \prime} \mathrm{E}$ & \\
& $41^{\circ} 05^{\prime} 30.99^{\prime \prime} \mathrm{N}$ & \\
Akçay Stream & $37^{\circ} 07^{\prime} 20.89^{\prime \prime} \mathrm{E}$ & April 2016 \\
& $41^{\circ} 09^{\prime} 34.03^{\prime \prime} \mathrm{N}$ & \\
Terme Stream & $36^{\circ} 53^{\prime} 28.48^{\prime \prime} \mathrm{E}$ & June 2015 \\
& $41^{\circ} 28^{\prime} 55.48^{\prime \prime} \mathrm{N}$ & \\
Engiz Stream & $36^{\circ} 02^{\prime} 49.58^{\prime \prime} \mathrm{E}$ & August 2016 \\
\hline
\end{tabular}

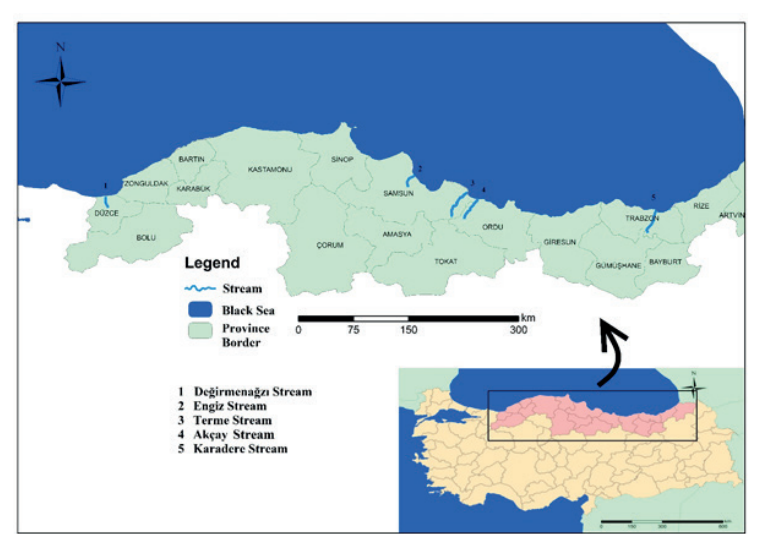

Figure 1. The map of study

50 samples from each locality were invastigated for systematic position of Crimean barbel. Identification of the specimens was conducted following relevant literature (Geldiay and Balık, 2007; Kottelat and Freyhof, 2007; Polat and Uğurlu, 2011). A total of 49 samples for genetic studies were utilized in the laboratuary. 


\section{DNA extraction}

Caudal fin tissue of each samples were preserved in $98 \%$ ethanol and stored at $-20^{\circ} \mathrm{C}$ until DNA extraction. Total genomic DNA was extracted from $15-20 \mathrm{mg}$ of tissue by the INVITROGEN, PureLinkTM Genomic DNA Tissue Kit using the following the manufacturer's protocol.

\section{PCR amplifications and sequencing of cyt $\boldsymbol{b}$}

Fragment of the mtDNA, cyt $b$ gene (1141 bp) was amplified by PCR using the following primers: the entire mitochondrial cyt $b$ gene was amplified with primers located within the Glu tRNA (5'GAAGAACCACCGTTGTTATTC-3') and Thr tRNA genes (5'-GATCTTCGGATTACAAGACC-3') PCR was performed at $95{ }^{\circ} \mathrm{C}$ for $4 \mathrm{~min}$, followed by 35 cycles at $95^{\circ} \mathrm{C}$ for $30 \mathrm{~s}, 50{ }^{\circ} \mathrm{C}$ for $30 \mathrm{~s}, 72^{\circ} \mathrm{C}$ for $1 \mathrm{~min}$ $30 \mathrm{~s}$, and a final extension at $72{ }^{\circ} \mathrm{C}$ for $5 \mathrm{~min}$. PCR products were visualized in $1.5 \%$ agarose low-meltingpoint gels stained with ethidium bromide for band characterization via ultraviolet transillumination.

Sequencing was performed directly using the corresponding both forward and reverse PCR primers. Sequence analysis was carried out at the Macrogen sequencing service (Macrogen Inc., Amsterdam, Netherlands).

\section{Sequence alignment and genetic analysis}

Nucleotide sequences were initially aligned using Clustal X (Thompson et al., 1994) and the final alignment was done manually with BioEdit (Hall, 1999). mtDNA was analyzed to assess levels of pairwise nucleotide variation and determine the nucleotide composition for each population using MEGA 5 (Tamura et al., 2011). The number of haplotypes $(\mathrm{H})$, haplotype diversity $(h)$, nucleotide diversity $(\pi)$, and the average number of nucleotide substitutions (K) were calculated using DnaSP v.5.10 (Librado and Rozas, 2009). Intra and interpopulation genetic diversity was measured by the maximum likelihood estimation of the average number of nucleotide substitutions per site within and between populations (Nei, 1987). jModelTest v.0.1 (Posada, 2008) indicated that the best-fitting model of nucleotide substitution by Akaike Information Criterion (AIC) and Bayesian Information Criterion (BIC). Neighbor-Joining (NJ: Saitou and Nei, 1987), Maximum Parsimony (MP) and Maximum Likelihood (ML) algorithms are used to determine the phylogenetic relationships between populations. Relationships between the haplotypes and concordance with geographic sampling locations were assessed by constructing a statistically parsinomy network at the $95 \%$ confidence interval using TCS 1.21 (Clement et al., 2000).

Maximum-likelihood phylogenetic analyses were performed using the BEST approach implemented in PhyML, version 3.0.1, which combines NNI (nearest neighbor interchanges) and SPR (subtree pruning and regrafting) algorithms to maximize tree likelihood (Guindon and Gascuel 2003), and using the TIM1+I+G models with parameters estimated by jModelTest (Posada 2008): the base frequencies $A=0.3068$, $\mathrm{C}=0.3029, \mathrm{G}=0.1286, \mathrm{~T}=0.2617$, and the gamma shape parameter equal to $2.2500,-\operatorname{lnL}=4433.6746$ for $c y t b$.

Phylogenetic relationships were inferred using different analytical approaches, performed with PAUP version 4.0b10 (Swofford, 2003) and PHYLIP v.3.68 (Felsenstein, 1993). Maximum parsimony (MP) analysis was conducted assuming equal weightings for all characters.

The population genetic structure was assessed by analyzing the molecular variance (AMOVA) (Excoffier et al., 1992) in ARLEQUIN v.2.0 (Schneider et al., 2000). SplitsTree (Huson and Bryant, 2006) were used to determine the relationships between haplotypes as another approach. Barbus and Luciobarbus species from GenBank database (AF090781, AF090780, KC465948, AF095605, AF145935, AF090784, AF090782, AF090791, AF090789, AF090786, AF095603 and AF090779) and also Cyprinus carpio (DQ868874.1-outgroup) were used in analyses

\section{RESULTS}

\section{Sequence composition, nucleotide and}

\section{haplotype diversity}

In the present study, complete cyt $b$ sequences (1141 bp) of B. tauricus from different localities were aligned. Among the 1141 nucleotide sites, $33 \mathrm{bp}$ (2.89\%) were variable, $31 \mathrm{bp}(2.71 \%)$ were parsimonyinformative across all samples. MtDNA cyt $b$ sequences have already been used in inferring phylogenetic relationships among species (Brito et al., 1997; Machordom and Doadrio, 2001). Average nucleotide composition of adenine (A), thymine $(T)$, cytosine $(C)$, guanine (G) were examined as $28.11 \%, 27.19 \%, 29.26 \%$ and $15.37 \%$, respectively. Sequence analysis of cyt $b$ revealed 11 different haplotypes (Table 2 ). $h$ and $\pi$ were estimated as 0.7491 and 0.00474 . The most common of the haplotypes identified was the Hap 4 (Table 3 )

$\mathrm{NJ}, \mathrm{MP}, \mathrm{ML}$ trees were drawn using $\mathrm{TIM} 1+\mathrm{I}+\mathrm{G}$ model (Figure 2, Figure 3, Figure 4). The cyt $b$ sequences for 11 haplotypes were submitted in GENBANK under accession number MH013040-MH010350. Hap 6 (MH010345), Hap 7 (MH010346), Hap 10 (MH010349) were found to be at a different level from the other haplotypes (Figure 5). When the matrices of the pairwise relations of these three haplotypes were examined, it was observed that they were different from other haplotypes. The highest genetic distance was calculated between Hap 2 and Hap 7 (0.0117). 
Table 2. Distribution of cyt $b$ haplotypes determined for Crimean barbel sampled from the Black Sea Region (AS: Akçay Stream, ES: Engiz Stream, KS: Karadere Stream, TS: Terme Stream, DS: Değirmenağzı Stream)

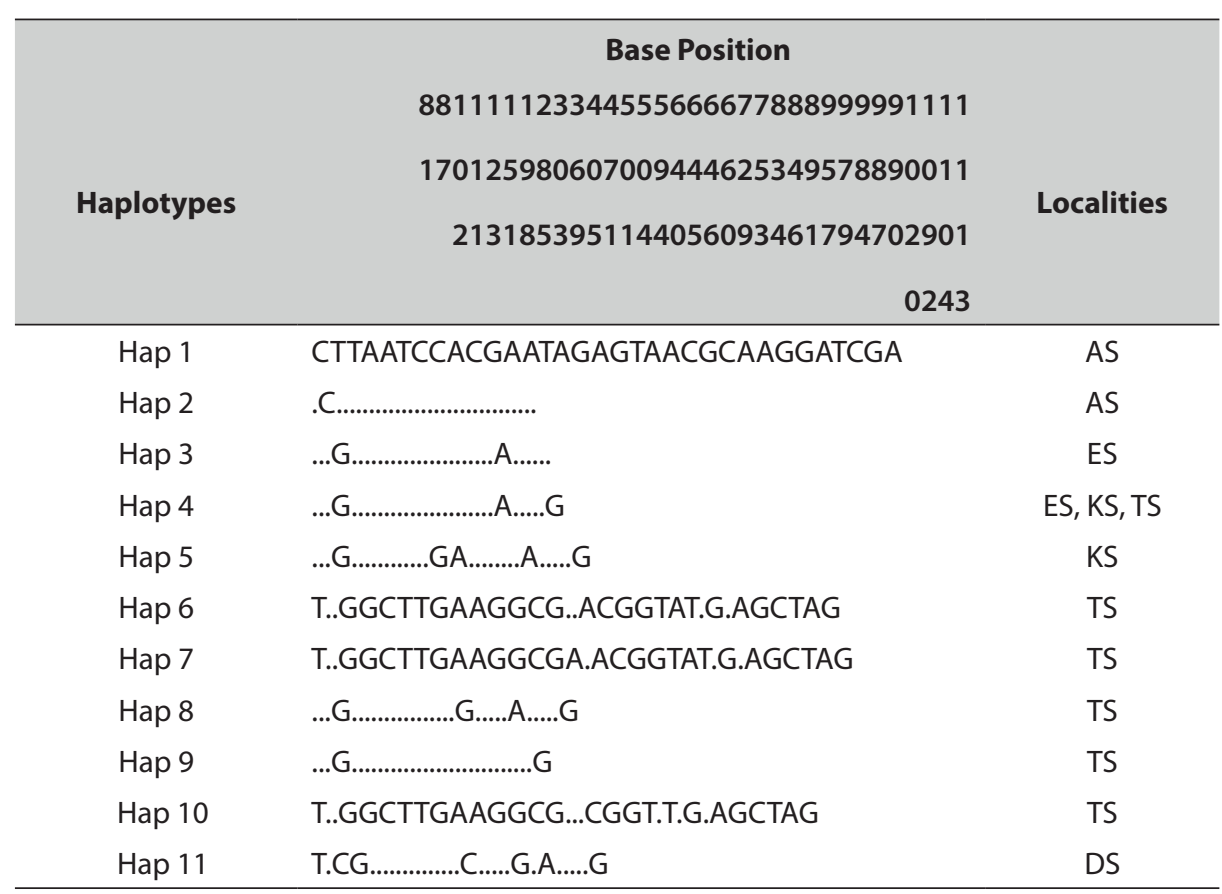

Table 3. Distribution and frequency of cyt $b$ haplotypes of B. tauricus populations (AS: Akçay Stream, ES: Engiz Stream, KS: Karadere Stream, TS: Terme Stream, DS: Değirmenağzı Stream)

\begin{tabular}{ccccccc}
\hline Haplotypes & AS & ES & KS & TS & DS & Total \\
\hline Hap 1 & 6 & - & - & - & - & 6 \\
Hap 2 & 3 & - & - & - & - & 3 \\
Hap 3 & - & 1 & - & - & - & 1 \\
Hap 4 & - & 10 & 9 & 3 & - & 22 \\
Hap 5 & - & - & 1 & - & - & 1 \\
Hap 6 & - & - & - & 1 & - & 1 \\
Hap 7 & - & - & - & 1 & - & 1 \\
Hap 8 & - & - & - & 1 & - & 1 \\
Hap 9 & - & - & - & 2 & - & 2 \\
Hap 10 & - & - & - & 1 & - & 1 \\
Hap 11 & - & - & - & - & 10 & 10 \\
Total & 9 & 11 & 10 & 9 & 10 & 49 \\
\hline
\end{tabular}




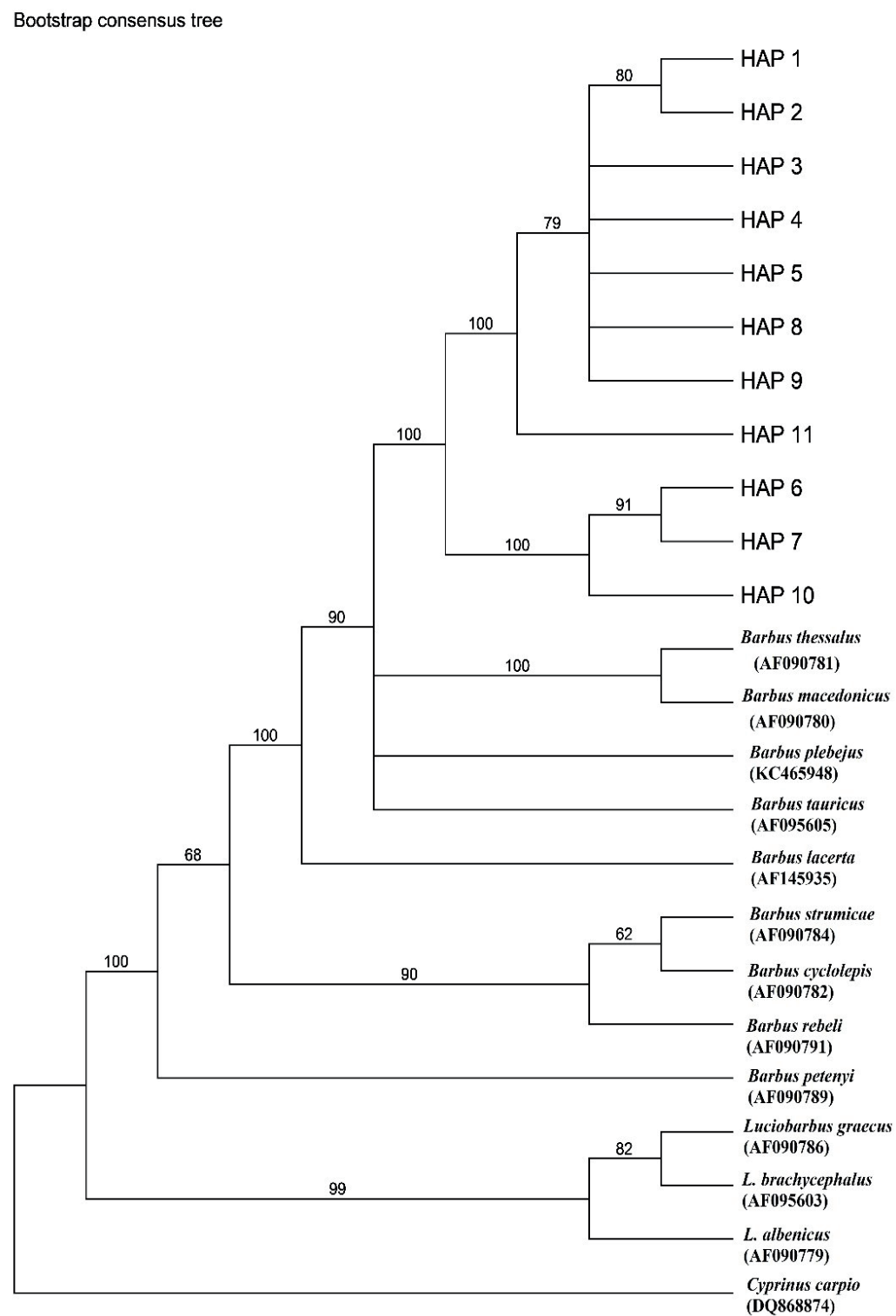

Figure 2. The NJ tree model was constructed for the cyt $b$ gene region of the $B$. tauricus (1000 replicates) 


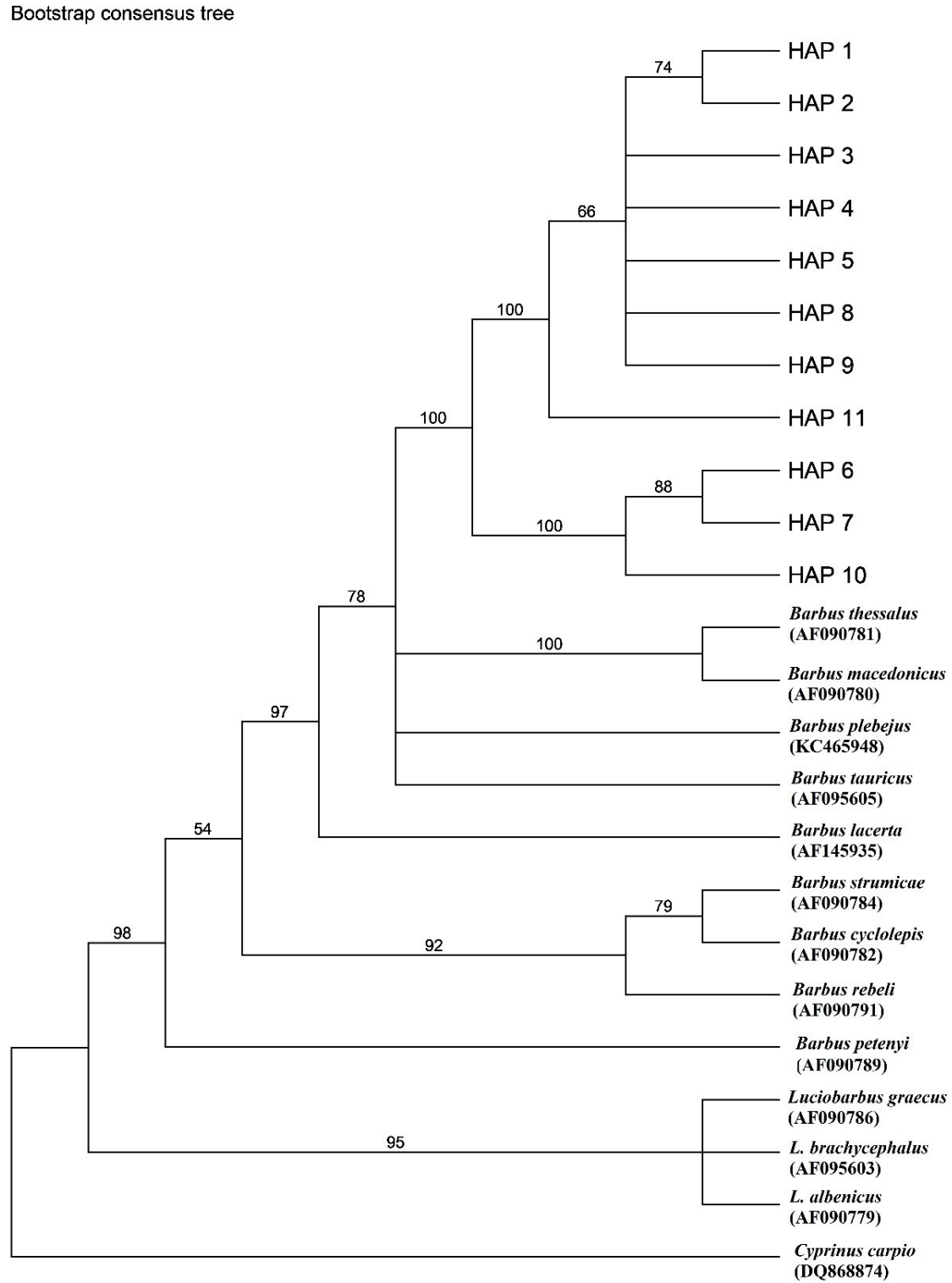

Figure 3. The MP tree model was constructed for the cyt $b$ gene region of the $B$. tauricus (1000 replicates) 


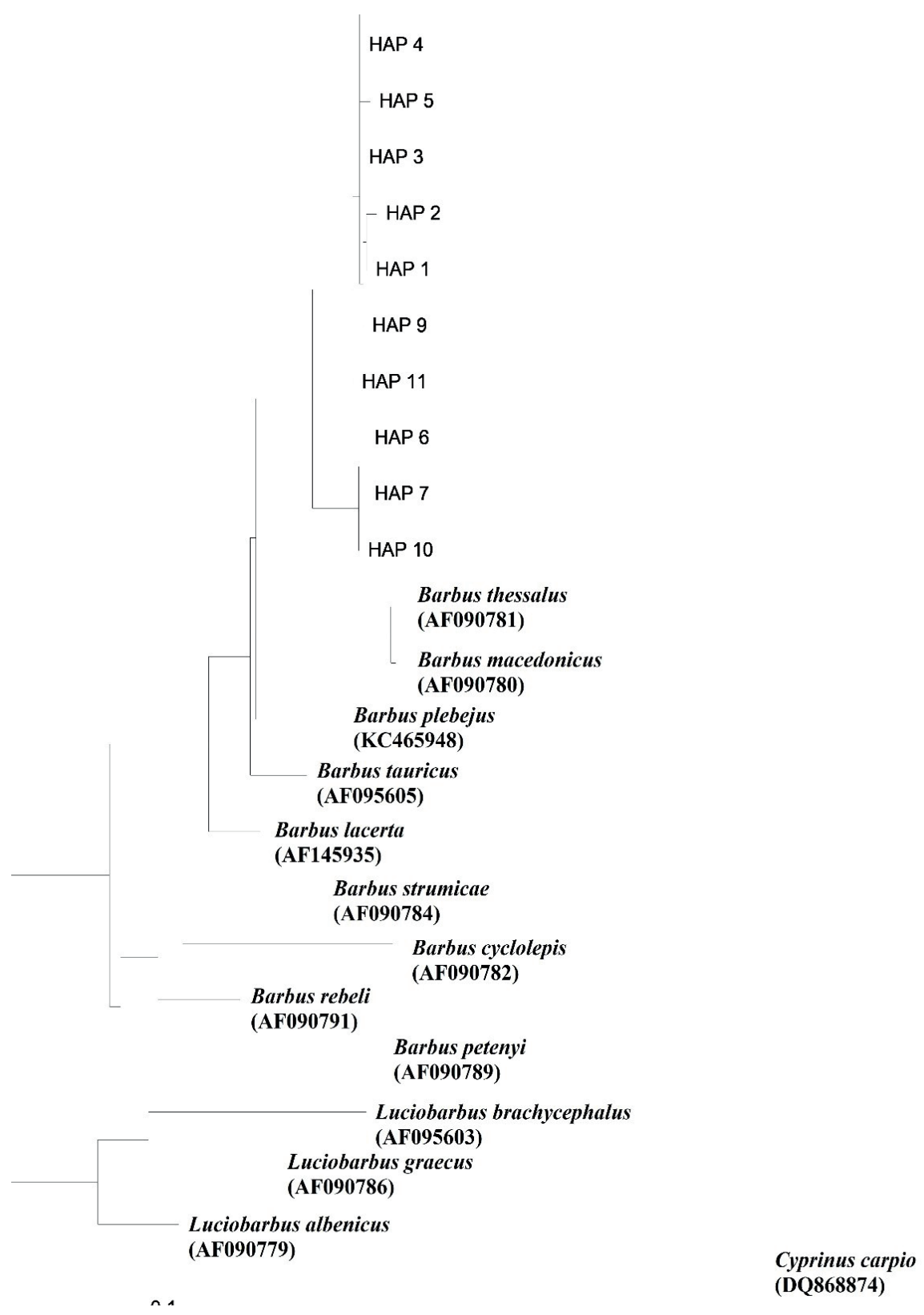

Figure 4. The ML tree model was constructed for the cyt $b$ gene region of the $B$. tauricus (1000 replicates) 


\section{Molecular variance analysis (AMOVA)}

AMOVA was performed using the ARLEQUIN for the analysis of the hierarchical distribution of the variance components. Assessment of the population structure

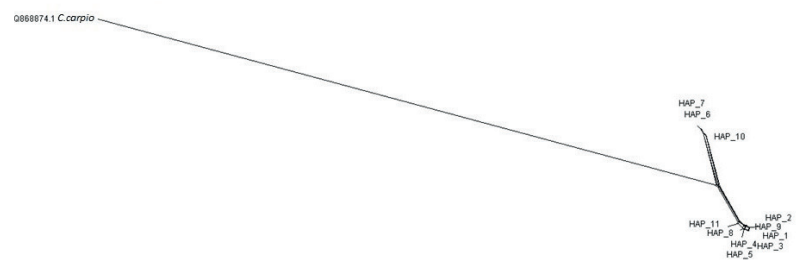

Figure 5. The tree model created using the SplitsTree program for the cyt $b$ gene region

is an important part of population genetics. Variance components in groups, within groups, between populations, and within populations were tested against null distribution. It was found that $26.61 \%$ of the obtained findings were distributed among the groups, $32.70 \%$ among the populations within the groups and $40.69 \%$ within the populations for cyt $b$ gene of 5 populations. The proportion of 'within the population' variance component is large (40.69\%) and the variance components for the comparisons were statistically significant $(P<0.001)$ (Table 4). Multisample and multilocus FST values were found to be significantly higher than zero (FST $=0.59310$ ), and the FST value calculated for all populations and loci confirms genetic heterogeneity in B. tauricus populations.

\section{DISCUSION}

The Barbel is a complex polyphyletic group of Old World Cyprinidae that provides a fantastic model for studying evolutionary phenomena in freshwater fish (Berrebi, 1995). The genus Barbus has been described by Myers (1961) as a 'monstrous aggregation'. At the present time, it is known that there are more than 1000 species of this genus together with their synonym names. The study of the speciation of the genus Barbus is an indirect means of understanding the evolution of the freshwater fish fauna and particularly that of the north Mediterranean basin (Berrebi, 1995). At the end of the Pleistocene, there was a giant freshwater lake in the Black Sea basin, which persisted for thousands of years and only became a sea in the Early Holocene (Ryan et al., 1997).

According to the phylogeographical evidence, this ancient lake system provided glacial refugia for fluviolacustrine barbels. Among these species included in genus Barbus, B. tauricus is one of the species with the widest distribution area. The main objective of this study was to detect genetic variability within and between the populations of crimean barbel.

Cyt $b$ gene has been preferred for both in-species and interspecific variations in many studies (Berrebi, 1995; Callejas and Ochando, 2002; Kartavtsev and Lee, 2006; Sakai et al., 2009; Markovà et al., 2010; Zheng et al., 2016; Behera et al., 2017; Kumar et al., 2017). There are some studies about genetic structure of Barbus species from different regions performed on understanding the phylogeny among the species. Those studies were focused on sequence of only mtDNA data of a single or few specimens from each species (Tsigenopoulos and Berrebi, 2000; Machordom and Doadrio, 2001). However, there is no study that examines the variation among populations of $B$. tauricus. Tsigenopoulus et al (2002) investigated complete sequences of the cyt $b$ in order to infer phylogenetic relationships between diploid, tetraploid and hexaploid 'Barbus' species is occurring in southern Africa. Kotlík et al (2004) reported sequence variation at the cyt $b$ gene (1141

Table 4. Results of AMOVA analysis for B. tauricus

\begin{tabular}{ccccccccc}
\hline $\begin{array}{c}\text { Source of } \\
\text { Variation }\end{array}$ & df & $\begin{array}{c}\text { Sum of } \\
\text { Squares }\end{array}$ & $\begin{array}{c}\text { Variance } \\
\text { Componets }\end{array}$ & $\begin{array}{c}\text { Percentage } \\
\text { of variation }\end{array}$ & $\mathbf{F}_{\text {IS }}$ & $\mathbf{F}_{\text {ST }}$ & $\mathbf{F}_{\text {IT }}$ & P value \\
\hline $\begin{array}{c}\text { Among groups } \\
\text { Among }\end{array}$ & 2 & 49.757 & 0.84961 & 26.61 & $0.5931^{*}$ & & $<0.001$ \\
$\begin{array}{c}\text { populations } \\
\text { within }\end{array}$ & 2 & 22.926 & 1.04373 & 32.70 & $0.4455^{*}$ & & $<0.001$ \\
$\begin{array}{l}\text { groups } \\
\text { Within }\end{array}$ & 44 & 57.154 & 1.29894 & 40.69 & & & & \\
populations \\
$\quad$
\end{tabular}


bp) to assess the phylogeography of Barbus fishes in the Black Sea Region and indicate that the refugial Barbus populations remain as geographical isolates in the Black Sea region, continuing to diverge genetically from each other and from remaining populations. In this study, complete sequence (1141 bp) of cyt $b$ was obtained, too. The results of present study also reveal the necessity of a genus-based revision because of phylogeographical lineages identified in the Black Sea barbels as suggested by Kotlík et al (2004). Zordoya and Doadrio (1999) were investigated evolutionary and biogeographical patterns of European Cyprinids, the results of that study provide a phylogenetic framework which turns out to be very useful in revising the systematics of some Barbus species. Tsigenopoulos and Berrebi (2000) were investigated molecular phylogeny of North Mediterranean freshwater Barbus species (21 different species except $B$. tauricus) inferred from cyt $b$ sequences and observed important genetic divergence among species and subspecies of the genus Barbus and confirm the necessity for a taxonomic revision. The data obtained from the cyt $b$ could help to identify new species. Antal et al. (2016) were discovered and described a new Barbus species, B. biharicus according to cyt $b$ sequence data. Similarly, according to the results of this study, Hap 6, Hap 7, Hap 10 were different from the other haplotypes (Figure 5). That was interesting that these differences were not supported by morphological studies. The authors were planning more detailed studies on this subject.

AMOVA analysis was conducted to observe how genetic variation was distributed among populations and within populations. The results of AMOVA showed the presence of high $(40.69 \%)$ within population variation which favored the haplotype differentiation.

\section{REFERENCES}

Aboim, M.A., Menezes, M.G., Schlitt, D. \& Rogers, A.D. (2005). Genetic structure and history of populations of the deep-sea fish Helicolenus dactylopterus (Delaroche, 1809) inferred from mtDNA sequence analysis. Molecular Ecology, 14: 1343-1354. DOI: 10.1111/j.1365-294X.2005.02518.x

Adams, D.C., Rohlf, F.J. \& Slice, D.E. (2004). Geometric morphometrics: ten years of progress following the 'revolution'. Italian Journal of Zoology, 71: 5-16. DOI: 10.1080/11250000409356545

Allendorf, F.W., Ryman, N. \& Utter, F. (1987). Genetics and Fishery Management. (Editors: N. Ryman, Utter F.), in Past, Present and Future in Pop. Gen. Fish. Man., University of Washington Press, Seattle and London.

Antal, L., László, B., Kotlík, P., Mozsár, A., Czegléd, I., Oldal, M., Kemenesi, G., Jakab, F. \& Nagy, S.A. (2016). Phylogenetic evidence for a new species of Barbus in the Danube River basin. Molecular Phylogenetics and Evolution, 96: 187-1941.

DOI: 10.1016/j.ympev.2015.11.023
Livi et al (2013) evaluated the molecular and morphometric properties of the Barbus species sampled from Italy and reported $29.80 \%$ of Barbus spp. diversity within populations and $63.78 \%$ among groups. The results of the AMOVA analysis revealed that there were genetic differences among the populations $(P<0.001)$. The FST value is different from 0 and it is determined that this difference is statistically significant (Table 4).

Genetic differentiation is important for developing strategies for conservation and management of a fish species. The genetic variations present in different fish stocks of a species affect the stocking programs and other related propagation practices (Allendorf et al., 1987; Clarke et al., 2015; Behera et al., 2017).

This study was carried out to investigate the genetic diversity of $B$. tauricus living in some freshwater sources along the coast of Black Sea Region and to identify genetic differences using cyt $b$ region. Cytochrome $b$ sequences seem to provide a basis source of information that can improve taxonomic classification. Our genetic analyses revealed that $B$. tauricus populations are geographically structured, and this study will be useful in differentiating intra-specific genetic diversity in populations. Consequently, the results of the study should help planning the fisheries management and genetic conservation studies.

\section{ACKNOWLEDGEMENTS}

This study was financially supported by Ondokuz Mayis University (Project No: PYO. 1901.13.008). We want to thank to Ondokuz Mayis University Project Office. This study is a part of the PhD thesis of Melek Özpiçak supervisored by Nazmi Polat.

Avise, J.C. (1986). Mitochondrial DNA and the evolutionary genetics of higher animals. Philoshophical Transactions Royal Society B, 312: 325-342.

Bănărescu, P. \& Bogutskaya, N.G. (2003). Barbus Cuvier, 1816: The Freshwater Fishes of Europe Volume 5/II: (Cyprinidae 2/II): Barbus. Aula Verlag GmbH, Wiebelsheim, Germany (GR), p. 1-10.

Behera, B.K., Kunal, S.P., Baisvar, V.S., Meena, D.K., Panda, D., Pakrashi, S, Paria, P., Das, P., Debnath, D., Parida, P.K., Das, B.K. \& Jena, J. (2017). Genetic variation in wild and hatcery population of Catla catla (Hamilton, 1822) analyzed through mtDNA cyt $b$ region. Mitochondrial DNA Part A, 29: 126-131. DOI: 10.1080/24701394.2016.1253072

Berrebi, P. (1995). Speciation of the genus Barbus in the North Mediterranean basin: Recent advances from biochemical genetics. Biological Conservation, 72: 237-249. DOI: 10.1016/0006-3207(94)00086-6. 
Brito, R.M., Briolay, J., Galtier, N., Bouvet, Y. \& Coelho, M.M. (1997) Phylogenetic relationships within genus Leuciscus (Pisces, Cyprinidae) in Portuguese fresh waters, based on mitochondrial DNA cytochrome $b$ sequences. Molecular Phylogenetics and Evolution, 8: 435-442. DOI: 10.1006/mpev.1997.0429

Cabral, H.N., Marques, J.F., Rego, A.L., Catarino, A.l., Figueiredo, J. \& Garcia, J. (2003). Genetic and morphological variation of Synaptura lusitanica Capello, 1868, along the Portuguese coast. Journal of Sea Research, 50: 167-175. DOI: 10.1016/S1385-1101(03)00060-1

Cadrin, S.X. (2000). Advances in morphometric identification of fisheries stocks. Reviews in Fish Biology and Fisheries, 10: 91-112.

Callejas, C. \& Ochando, M.D. (2002). Phylogenetic relationships among Spanish Barbus species (Pisces, Cyprinidae) shown by RAPD markers. Heredity, 89: 36-43. DOl:10.1038/sj.hdy.6800091

Clarke, C.R., Karl, S.A., Horn, R.L., Bernard, A.M., Lea, J.S., Hazin, F.H., Prodöhl, P.A. \& Shivji, M.S. (2015). Global mitochondrial DNA phylogeography and population structure of the silky shark, Carcharhinus falciformis. Marine Biology, 162: 945-955.

Clement, M., Posada, D. \& Crandall, K.A. (2000). TCS a computer program to estimate gene genealogies. Molecular Ecology, 9: 1657-1660. DOI: 10.1046/j.1365-294x.2000.01020.x

Excoffier, L., Smouse, P.E. \& Quattro, J.M. (1992). Analysis of molecular variance inferred from metric distances among DNA Haplotypes: Application to Human Mitochondrial DNA Restriction Data. Genetics, 131: 479-491.

Geldiay, R., \& Balık, S. (2007). Freshwater Fishes of Turkey, İzmir, Turkey (TR), Ege Üniversitesi Su Ürünleri Fakültesi Yayınları.

Gilles, A., Lecointre, G., Faure, E., Chappaz, R. \& Brun, G. (1998) Mitochondrial Phylogeny of the European Cyprinids: Implications for Their Systematics, Reticulate Evolution, and Colonization Time. Molecular Phylogenetics and Evolution, 10: 132-143. DOI: $10.1006 / \mathrm{mpev} .1997 .0480$

Guindon, S. \& Gascuel, O. (2003). A simple, fast and accurate method to estimate large phylogenies by maximum-likelihood. Systematic Biology, 52: 696-704.

Felsenstein, J. (1993). Phylogeny Inference Package (PHYLIP). Version 3.5. University of Washington, Seattle.

Hall, T.A. (1999). BioEdit: a user-friendly biological sequence alignment editor and analysis program for Windows 95/98/NT. Nucleic Acids Symposium Series, 41: 95-98.

He, S., Mayden, R.L., Wang, X., Wang, W., Tang, K.L., Chen, W.C. \& Chen, Y. (2008). Molecular phylogenetics of the family Cyprinidae (Actinopterygii: Cypriniformes) as evidenced by sequence variation in the first intron of S7 ribosomal proteincoding gene: Further evidence from a nuclear gene of the systematic chaos in the family. Molecular Phylogenetics and Evolution, 46: 818-829. DOI: 10.1016/j.ympev.2007.06.001

Huson, D.H. \& Bryant, D. (2006). Application of phylogenetic networks in evolutionary studies. Molecular Biology and Evolution, 23: 254267. DOI: $10.1093 / \mathrm{molbev} / \mathrm{msj030}$

Im, Y.J., So, H.S., Ji, H.S., Myoung, S.H. \& Kim, J.K. (2017). Geographic variations of the mottled skate, Beringraja pulchra (Liu, 1932) (Rajidae) in the Yellow and East seas based on molecular and morphometric data. Journal of Applied Ichthyoogy, 33: 950-956. DOI: $10.1111 /$ jai.13408
Kartavtsev, Y.P. \& Lee, J.S. (2006). Analysis of nucleotide diversity at the cytochrome $b$ and cytochrome oxidase 1 genes at the population, species, and genus levels. Russian Journal of Genetics, 42: 341-362.

Kartavtsev, Y.P., Batischeva, N.M., Bogutskaya, N.G., Katugina, A.O. \& Hanzawa, N. (2017). Molecular systematics and DNA barcoding of Altai osmans, oreoleuciscus (pisces, cyprinidae, and leuciscinae), and their nearest relatives, inferred from sequences of cytochrome b (Cyt-b), cytochrome oxidase c (Co-1), and complete mitochondrial genome. Mitochondrial DNA Part A, 28: 502-517. DOI: 10.3109/24701394.2016.1149822.

Kotlík, P., Bogutskaya, G. \& Ekmekçi, F.G. (2004). Circum Black Sea phylogeography of Barbus freshwater fishes: divergence in the Pontic glacial refugium. Molecular Ecology, 13: 87-95. DOI: $10.1046 /$ j.1365-294X.2003.02021.x

Kotlík, P., Marková, S., Choleva, L., Bogutskaya, N.G., Ekmekçi, F.G. \& Ivanova, P.P. (2008). Divergence with gene flow between PontoCaspian refugia in an anadromous cyprinid Rutilus frisii revealed by multiple gene phylogeography. Molecular Ecology, 17: 10761088. DOI: 10.1111/j.1365-294X.2007.03638.x

Kottelat, M. \& Freyhof, J. (2007). Handbook of European Freshwater Fishes. Cornol, Switzerland and Freyhof, Berlin, Germany (GR).

Kumar, R., Pandey, B.K., Sarkar, U.K., Nagpure, N.S., Baisvar, V.S, Agnihotri, P., Awasthi, A., Misra, A. \& Kumar, N. (2017). Population genetic structure and geographic differentiation in butter catfish, Ompok bimaculatus, from Indian waters inferred by cytochrome $b$ mitochondrial gene. Mitochondrial DNA Part A, 28: 442-450. DOI: 10.3109/19401736.2015.1137898

Li, D., Kang, D., Yin, Q., Sun, X. \& Liang, L. (2007). Microsatellite DNA marker analysis of genetic diversity in wild common carp (Cyprinus carpio L.) populations. Journal of Genetics and Genomics (Formerly Acta Genetica Sinica), 34: 984-993. DOI: 10.1016/S1673-8527(07)60111-8

Librado, P. \& Rozas, J. (2009). DnaSP v.5: A software for comprehensive analysis for DNA polymorphism data. Bioinformatics, 25: 14511452.

Livi, S., de Innocentiis, S., Longobardi, A., Cataudella, S, Tancioni, L, Rampacci, M. \& Marino, G. (2013). Genetic structure of Barbus spp. populations in the Marches Region of central Italy and its relevance to conservation actions. Journal of Fish Biology, 82: 806-826. DOI: 10.1111/jfb.12021

Machordom, A. \& Doadrio, I. (2001). Evolutionary history and speciation modes in the cyprinid genus Barbus. Proceedings of the Royal Society of London, Series B, 268: 1297-1306. DOI: 10.1098/rspb.2001.1654

Maes, G.E., Van Haudt, J.K.J., De Charleroy, D. \& Volckaert, F.A.M. (2003). Indications for a recent Holarctic expansion of pike based on a preliminary study of mtDNA variation. Journal of Fish Biology, 63: 254-259. DOI: 10.1046/j.1095-8649.2003.00140.x

Mahe, K., Villanueva, M.C., Vaz, S., Coppin, F., Koubbi, P. \& Carpentier, A. (2014). Morphological variability of the shape of striped red mullet Mullus surmuletus in relation to stock discrimination between the Bay of Biscay and the eastern English Channel. Journal of Fish Biology, 84: 1063-1073. DOI: 10.1111/jfb.12345

Marková, S., Šanda, R., Crivelli, A., Shumka, S., Wilson, I.F., Vukic, 
J., Berrebi, P. \& Kotlík, P. (2010). Nuclear and mitochondrial DNA sequence data reveal the evolutionary history of Barbus (Cyprinidae) in the ancient lake systems of the Balkans. Molecular Phylogenetics and Evolution, 55: 488-500. DOI: 10.1016/j.ympev.2010.01.030

Murta, A.G. (2000). Morphological variation of horse mackerel (Trachurus trachurus) in the Iberian and North African Atlantic: Implications for stock identification. ICES Journal of Marine Science, 57: 1240-1248. DOI: 10.1006/jmsc.2000.0810

Myers, G.S. (1961). Preface to any future classification of the Cyprinid fishes of the genus Barbus. Standford Ichthyological Bulletin, 7: 212-215.

Myoung, S.H.\& Kim, J.K. (2014). Genetic diversity and population structure of gizzard shad, Konosirus punctatus (Clupeidae, Pisces) in Korean waters based on mitochondrial DNA control region squences. Genes and Genomics, 36: 591-598.

Nei, M. (1987). Molecular Evolutionary Genetics. Columbia University Press.

Pinheiro, A., Teixeira, C.M., Rego, A.L., Marques, J.F. \& Cabral, H.N. (2005). Genetic and morphological variation of Solea lascaris (Risso1810) along the Portuguese coast. Fisheries Research, 73: 67-78. DOI: 10.1016/j.fishres.2005.01.004

Polat, N. \& Uğurlu, S. (2011). Samsun Illi Tatlı Su Balık Faunası, Turkey (TR), Ceylan Ofset Baskı.

Posada, D. (2008). jModelTest: Phylogenetic Model Averaging. Molecular Biology and Evolution, 25: 1253-1256.

Raven, P.H. \& Johnso, G.B. (1995). Biology (updated version). Third Edition. Wm. C. Brown publishers, Dubuque, lowa. 399: 404-422.

Ryan, W.B.F., Pitman, W.C.III, Major, C.O., Shimku, K., Moskalenko, V., Jones, G.A., Dimitrov, P., Görür, N., Sakinç, M. \& Yüce, H. (1997). An abrupt drowning of the Black Sea shelf. Marine Geology, 138: 119126. DOI: 10.1016/50025-3227(97)00007-8

Rylková, K. \& Kalous, L. (2013). Genetic diversity in the genus Carassius (Teleostei: Cyprinidae) in the Czech Republic. Acta Societatis Zoologicae Bohemicae, 77: 73-79.

Saccone, C., Gissi, C., Laneve, C., Larizza, A., Pesole, G. \& Reyes, A. (2000). Evolution of the mitochondrial genetic system an overview. Gene, 261: 153-159. DOI: 10.1016/S0378-1119(00)00484-4

Saitou, N. \& Nei, M. (1987). The neighbor-joining method-a new method for reconstructing phylogenetic trees. Molecular Biology and Evolution, 4: 406-425.

DOI: 10.1093/oxfordjournals.molbev.a040454
Sakai, H., Iguchi, K., Yamazaki, Y., Sideleva, V.G. \& Goto, A. (2009). Morphological and mtDNA sequence studies on three crucian carps (Carassius: Cyprinidae) including a new stock from the $\mathrm{Ob}$ River system, Kazakhstan. Journal of Fish Biology, 74: 1756-1773. DOI: 10.1111/j.1095-8649.2009.02203.x

Schneider, S., Roessli, D. \& Excoffier, L. (2000). ARLEQUIN, Version 2.0: A Software for population genetic data analysis, Genetics and Biometry Laboratory, University of Geneva, Switzerland.

Sevilla, R.G., Diez, A., Noren, M., Mouchel, O., Jérome, M., Verres-Bagnis, V., Pelt, H.V., Favre-Krey, L., Krey, G. \& The Fishtrace Consortium et al. (2007). Primers and polymerase chain reaction conditions for DNA barcoding Teleost fish based on the mitochondrial cytochrome $b$ and nuclear rhodopsin genes. Molecular Ecology Notes, 7: 730-734. DOI: 10.1111/j.1471-8286.2007.01863.x

Stiling, P.D. (1992). Ecology: Theories and Applications. Prentice Hall, Upper Saddle River, NJ. 62-66.

Swofford, D.L. (2003). PAUP: Phylogenetic analysis using parsimony (and other methods) Sunderland, MA: Sinauer Associates.

Tamura, K., Peterson, D., Peterson, N., Stecher, G., Nei, M. \& Kumar, S. (2011). MEGA5: molecular evolutionary genetics analysis using maximum likelihood, evolutionary distance, and maximum parsimony methods. Molecular Biology and Evolution, 28: 27312739. DOI: $10.1093 / \mathrm{molbev} / \mathrm{msr} 121$

Thompson, J.D., Higgins, D.G. \& Gibson, T.J. (1994). Clustal W: improving the sensitivity of progressive multiple sequence alignment through sequence weighting, position-specific gap penalties and weight matrix choice. Nucleic Acids Research, 22: 4637-4680.

Tsigenopoulos, C.S. \& Berrebi, P. (2000). Molecular phylogeny of North Mediterranean freshwater barbs (Genus Barbus: Cyprinidae) inferred from cytochrome $b$ sequences: biogeographic and systematic implications. Molecular Phylogenetics and Evolution, 14: 165-179. DOI: $10.1006 / \mathrm{mpev} .1999 .0702$

Tsigenopoulos, C.S., Rab, P., Naran, D. \& Berrebi, P. (2002). Multiple origins of polyploidy in the phylogeny of southern African barbs (Cyprinidae) as inferred from mtDNA markers. Heredity, 88: 466473.

Zheng, L.P., Yang, J.X. \& Chen, X.Y. (2016). Moleculer phylogeny and systematics of the Barbinae (Teleostei: Cyprinidae) in China inferred from mitochondrial DNA sequences. Biochemical Systematics and Ecology, 68: 250-259. DOI: 10.1016/j.bse.2016.07.012Uteces nobissim ditium fugiae 